Revie w

\title{
APPROACHES FOR MANAGEMENT OF CHEMICAL SUBSTANCES: CHALLENGES AND SOLUTIONS
}

\author{
Kristīne Kazerovska, Māris Kḷaviṇš, and Judīte Dipāne \\ Faculty of Geography and Earth Sciences, University of Latvia, Raiņa bulv 19, LV-1586, Rīga, LATVIA \\ E-mail: kristine.kazerovska@inbox.Iv
}

Contributed by Māris Kḷaviṇš

\begin{abstract}
This article analyses the development of approaches for management of chemical substances in the frame of current reform of chemicals policy at the European Union level with regard to implementation of REACH Regulation No. 1907/2006. REACH is considered as an integrated approach to the control of the production, import and use of chemicals in the European Union, especially of those chemical substances with the most hazardous properties. The new approach covers both the strengths of old and new chemical policies, also requires revision of existing understandings about chemical production, import and use: responsibilities of all involved actors, the chemicals supply chain, and information flow within chemicals supply chain.
\end{abstract}

Key words: chemicals policy, EU regulations, REACH, chemicals supply chain.

\section{INTRODUCTION}

The chemical industry is particularly relevant for society's prosperity because a number of other economic sectors, such as metal processing, production of furniture, textiles, agriculture and others depend on it. In many countries the chemical industry largely supports the overall welfare of society and is an important segment in the formation of the gross domestic product.

The world's annual production of chemicals is estimated at 400 million tons. Of the six to seven million chemical substances known in industry and scientific research, close to 70000 have been produced for regular use in the industrial sectors, agriculture and service. Of this number, only a few thousand are produced in substantial quantities for industrial use. Various inventories have been established and different investigations have been carried out in order to estimate the number of existing chemicals on the market. 5-10\% marketed chemical substances are considered hazardous, of which 1500-2000 chemicals are known carcinogens (Anonymous, 1987). The number of commercial products containing mixtures of chemicals is unknown but is certainly many times higher, and due to the production of new chemicals products, this number is continuously changing. In addition, there are numerous materials, articles etc., that because of their chemical composition or treatment with chemicals, may be of interest regarding the management of chemical risks (Lonngren, 1992).

Many branches of industrial production (oil processing, textile industry, food processing, pharmaceutical industry) depend on the usage of chemical substances. Innovations in the chemical industry directly influence the availability of many products including pharmaceuticals. The contribution of the chemical industry to the European Union (EU) gross domestic product amounts to $1.3 \%$; when pharmaceuticals are added, this figure amounts to 2\% (Anonymous, 2007b). Also, considering the needs of society in the future, it is clear that progress and even sustainability cannot be achieved without developing chemical production. However, the chemical industry and many substances are perceived by the public as notorious, as many chemical substances can pose a risk to human health and environment, and their production can be a major threat for employees and the society. Chemical substances can directly contaminate the environment, posing a significant threat to human health and global environment, they can serve as precursors for the production of chemical weapons, illicit drugs, and industrial catastrophes can be a major threat for large regions (Walker et al., 2001). In this respect, the chemical industry very much differs from other branches of industrial production, and chemical substances differ from other industrial products.

The adverse impacts of chemical production have been recognised at rather early stages of the development of industrial production and in order to minimise negative impacts a number of legal acts in industrially developed countries have been developed with the aim to regulate production, use, and utilisation of chemicals (Lonngren, 1992). The intensity of self regulation, state regulation, control of chemical industry and approaches used in management of chemical substances very much differ from approaches common in other areas of production and management.

Currently, major changes are taking place with regard to chemical substances in the EU, introduced by Regulation 
No. 1907/2006 of the European Parliament and of the Council of 18 December 2006 concerning the Registration, Evaluation, Authorisation and Restriction of Chemicals (REACH) (Anonymous, 2006; Anonymous, 1998a). The main goal of this regulation is protection of public health and the environment, reduction of possible threats and risks in accordance with the precautionary principle. This principle advocates taking precautionary action when chemicals pose possible threats, rather than waiting for complete scientific proof of cause and effect (Lokke, 2006). In this respect approaches used for regulation of chemical industry and management of chemicals are highly innovative and may advance progress in respect of regulation of production and management.

The efficiency of implementation of REACH can influence many factors (existing legislation in other areas, understanding of roles and responsibilities of each actor in the chemicals supply chain, and adaptation to new communication ways in the supply chain to transfer information). A significant threat for implementation of the precautionary principle could be reduction of competitiveness of chemical industry in a specific country or country group (EU) in respect to countries not applying the suggested approaches.

The aim of this article is to review the process of development of chemical substance management, chemical flows and factors affecting its effectiveness and implementation.

\section{DEVELOPMENT OF APPROACHES IN MANAGE- MENT OF CHEMICAL SUBSTANCES}

For a long period of time classic concepts and definitions have coloured our view on chemicals and tempered approaches to benefit from chemicals without suffering negative consequences. A general conceptual approach is expressed by the sentence "Prevention is better than cure". In most countries regulatory control of chemicals began slowly with a focus on specific chemicals known to be toxic. Nowadays the broad approach considers all chemicals as potentially hazardous - consideration of multiple long term risks to both human health and the environment also require a thorough understanding of possible effects and sideeffects of the chemical substance (Lonngren, 1992).

Regulations which aim to investigate, communicate and take action on chemical properties are a key part of the chemicals management systems that protect human health and the environment. However, with many thousands of chemicals being produced and used, it is also one of the most complex and challenging aspects of regulations.

The regulations of chemicals use at the EU level started in the 1960 s. It is important to note that these regulatory systems refer to "substances" rather than "chemicals"-in many cases, a substance will be one chemical, but it may also be a mixture of chemicals, for example, a crude oil fraction. Within the EU and many other systems, certain other groups of chemicals are regulated separately, for ex- ample, pharmaceuticals, veterinary medicines, pesticides and radioactive substances. Chemical assessment and control legislative systems in many countries are comprehensive; also chemicals may be covered by more than one piece of legislation. Chemicals shall be regulated because they are chemicals, not because they are found in the environment or workplaces or anywhere else (Winder and Azzi, 2005).

Until 2007, the regulatory system covered the following components: classification and labelling, restrictions on marketing and use, new chemicals regulation, existing chemicals regulation.

The earliest EU chemical legislation, Council Directive $67 / 548 / \mathrm{EEC}$ created a system for standardising classification, packaging and labelling of dangerous substances (both industrial chemicals and pesticides), and has since been amended a number of times. Directive 1999/45/EC covers similar areas for "preparations"- a mixture of substances. The legislation specifies the criteria for classifying of the dangerous properties of the substances on properties and performs classification of substances (Anonymous, 1992). It should be noted that producers are under no obligation to actually perform any tests, the legislation includes no test or data requirements and classifications need only be made on the basis of available data. In fact a producer can classify a substance without safety data and more safety data may result in a higher classification, this system actually creates an incentive for the producer to avoid safety testing (Hansson and Ruden, 2006). Producers of substances and preparations that meet the criteria for classification as dangerous are also required to create a safety data sheet (SDS) containing information about the substance's properties and this SDS must be passed to users of chemicals (Anonymous, 1991).

Directive 76/769/EEC is known as a "limitations directive" that harmonises restrictions on the use of chemicals. Restrictions agreed under this directive usually only limit substances for specific use rather than banning them completely. Chemicals with certain classification, for example, classes 1 and 2 carcinogens, mutagens, and reproductive toxins (CMRs), are automatically restricted in that they cannot be sold to the public as substances or in preparations (Anonymous, 2005).

All chemicals on the European market between 1 January 1971 and September 1981 have been listed in the European Inventory of Existing Commercial Chemicals Substances (EINECS). This is a closed database; no substances have been added since the 1981 inventory.

The EINECS database has 100106 entries, although in reality there are actually fewer chemicals on the market. The latest data from the European Commission's Joint Research Centre suggested a more or less realistic number of chemicals (Pedersen et al., 2003). There is no requirement on industry to submit safety information for the chemicals on the EINECS database; however, they have been obliged to submit available data. In this respect the aim of the Existing Substances Regulation (793/93) is to assess the environ- 
ment and health risks of Existing Substances by setting priority lists for assessment using the data submitted by industry or other available data. There are currently 141 existing chemical on the priority lists; once a chemicals is on a priority list, there is an obligation of producers to submit a "base set" like New Chemicals notification.

The risk assessment produced under the existing chemicals programme is long and complex, requiring a significant workload from Member State and European Commission experts.

New Chemicals regulation, unlike regulation on restrictions on market and use, does not allow a substance on the market until it has gone through some sort of assessment. In the case of industrial chemicals, all those chemicals that have been introduced to the market at greater than $10 \mathrm{~kg} /$ year since 19 September 1981 (not on the EINECS list) have had to go through the "New Chemicals" notification procedure. All new substances are listed on the European List of Notified Chemical Substances (ELINCS) (Anonymous, 2005).

The new substances notification includes specific premarket testing and assessment, with testing requirements increasing with tonnage per notifier on the market, in six different tonnage bands. The notification should also include suggestions for classification and labelling and may include preliminary risk assessment. The final risk assessment is prepared by the Competent Authority of the Member States where the notification occurs, and this notification is accepted by other Member States. If the risk assessment concludes that the substance is of concern, then recommendations may be made to modify classification and labelling, the safety data sheet, or alternatively control measures could be recommended (Anonymous, 1998).

In theory, the existing (until 1 June 2007) EU system appears to create an effective methodology for assessing and managing the risks posed by chemicals. However, this has not proved to be the case, and in 1998 a review of European chemicals policy was initiated. There are several problems with the existing system: a lack of available information on the hazardous chemicals and uses of existing chemicals, a low level of innovations in the chemicals industry, unequal requirements for marketing and use between new chemicals and existing chemicals, inadequate division of responsibility: state authority is responsible more for risk assessment than producers, importers or users of chemicals. In the existing chemical supply chain some actors (downstream users) are not involved.

As the result of the deficiencies identified in the existing legislation, a process of stakeholder debate and internal discussion within the European Commission led to the proposal of a new system, Registration, Evaluation and Authorization of Chemicals (REACH), which was first outlined in a White paper in February 2001. This approach was supported by the other two pillars of European decision making: the Member State Governments (Council) in June 2001 and the European Parliament in November 2001.
REACH is designed to be an integrated approach to the control of the production, import and use of chemicals in Europe. It replaces most of the current chemicals regulatory system. The key aspects are:

- Registration is the process requiring producers and importers of substances to delivery safety and use data to the European Chemicals Agency. Producers and importers have obligation to produce a chemical safety report for their substances if it reaches a defined threshold.

- Evaluation includes several purposes-authorities will evaluate testing proposals identified by registrants in order to ensure safety of their products, check compliance with the requirements of the regulation and evaluate risks to human health and the environment arising from substances. Thus there are two types of evaluation: dossier evaluation-Member States' authorities will evaluate testing proposals with focus to avoid unnecessary testing on animals and substance evaluation if there is suspicion that it poses a risk to human health or the environment. European Chemicals Agency shall coordinate the process and the evaluation will be performed by Member States' authorities.

- Authorisation is a new procedure for controlling the use of chemicals of very high concern: Classes 1 and 2 carcinogens, mutagens and reproductive toxicants; persistent, bioaccumulative and toxic chemicals; very persistent and very bioaccumulative chemicals are identified as causing serious and irreversible effects to humans or the environment which are equivalent to the other chemicals above.

- Restriction process deals with chemicals that are exempt from registration and also leads to action being taken on existing chemicals that have not yet had to be registered.

REACH has many positive features, including an end to the arbitrary separation of new and existing chemicals, a strengthening of producer responsibility on chemical producers, an internet database on chemical safety and a new system for dealing with the chemicals of greatest concernthough many stakeholders wish to strengthen the role of substitution in this process (Warhurst, 2006).

\section{INFORMATION FLOW IN THE MANAGEMENT SYS- TEM OF CHEMICAL SUBSTANCES}

Due to many actors dealing with chemicals, the responsibilities, tasks and information sources need to be defined in order to ensure protection of human health and environment.

\section{Actors in the chemical supply chain}

There can be a long way for a chemical substance from its production till application in a chemical product (detergent, paint etc.) or other products (chair, dress etc.). The chemi- 


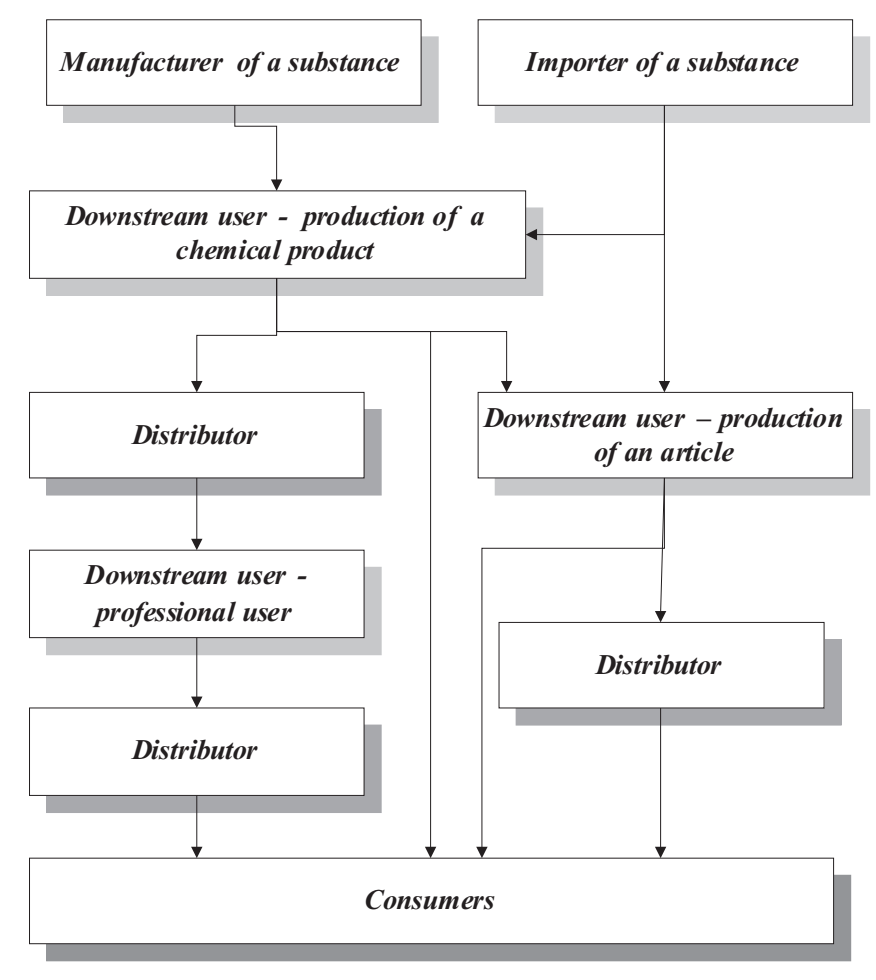

Fig. 1. An example of a chemical supply chain and the involved actors.

cals supply chain illustrates all actors, who have activities with chemicals like processing, formulation, consumption, storage, keeping, treatment, filling into containers, transfer from one container to another, mixing, production of an article or any other utilisation. Manufacturers, importers, downstream users, distributors and consumers are actors in the chemicals supply chain, which increase numerically down to the chemicals supply chain. Figure 1 illustrates an example of chemicals supply chain.

The information flow on chemical substance's properties starts from the top and travels along the supply chain. Manufacturers of the chemical substance are the main responsible actors for generating and providing information on substances to other actors. According to REACH, the importer has also the same responsibility, if he imports chemicals from non-European Union countries. In case of production or import of a substance exceeding 1 ton per year, the manufacturer or importer shall apply for registration in the European Chemical Agency and submit a set of data, which depends on the threshold. A chemical substance without a defined data set cannot be placed on the market (no data-no market!). In case of using particularly dangerous substances such as carcinogenic mutagenic and toxic for reproduction category 1 or 2 in accordance with Directive $67 / 548 /$ EEC, persistent, bioaccumulative and toxic, an authorisation is required and an obligation to reduce risks in the future. The manufacturer or importer of substances is obliged to assess risks and to develop measures of risk reduction, and disseminate information on hazardous properties via different information tools such as labelling, safety data sheet (Anonymous, 2006).
Professional users of chemicals in industrial processes, e.g. metal processing, production of furniture, textile etc., involve chemical preparations in their production and apply information for safety measures at work and for protection of the environment, evaluating potential risks of their products to human health and the environment. There are companies that use different substances to produce chemical preparations, e.g. paints for different purposes. According to REACH these actors are named as downstream users, which apply substances within a usually complex production process to serve and ensure specific purposes. For the downstream user it is important that these purposes are fulfilled. If there is an alternative with lower health and environmental risks, the downstream user will change inputs as long as costs remain constant. As the downstream user is frequently the link between manufactures and consumer market, any case of liability will bring him to public attention first. Environmental liability rules as well as civil law liability and criminal law are directed towards him, so that his incentive to reduce risks is rather high (Fuhr and Bizer, 2007). The downstream users formulating products are more aware of other downstream users and their needs than manufacturers or importers. At the same time their interest in disclosing information is not great, as they want to save their market potential. Manufacturers might have an incentive to share information with those downstream users in order to obtain more knowledge about downstream demands, and other downstream users might be interested in improving their products by providing information up to the supply chain (Fuhr and Bizer, 2007). Similarly to manufacturers and importers, downstream users formulate chemical preparations use the information tools and assess dangerous properties of chemical preparation based on received information. The downstream user has the right to pass information to the next actor up the chain in cases where the identified use is not described by the manufacturer or importer and proposed measures. This new element of information transfer for downstream users and the management approaches developed for chemical substances could be of definite value also for the development of environmentally safe management of dangerous products.

Distributors only store and place on the market a substance, on its own or in a preparation. They are responsible to ensure information flow up and down the supply chain. Distributors, like other actors who place chemicals on the market, have to ensure labelling of the chemicals into the national language in cases where a product is from another EU country, such that each user of the chemical product can understand information on safety measures and instructions of use.

At the bottom of the chemicals supply chain are numerously the biggest part of actors-consumers, who use the produced chemical preparations, products or rarely chemical substances in households. The main source of information for consumers on hazardous properties of chemical preparation is labelling in order to apply risk reduction measures. 
Due to new responsibilities and tasks in the supply chain, each actor needs to understand his role and activities to be done, which may take a certain time, knowledge and resources. Since REACH requires that any actor in the supply chain of a substance or a preparation shall communicate to the next actor new information on hazardous properties, and any other information related to risk management measures shall be identified in a safety data sheet. The transfer of information through the supply chain will place new burdens on business. It is therefore important that this aspect of $\mathrm{REACH}$ is enforced in such a way as to ensure a level playing field for business (Anonymous, 2007a). Problematic cases can be expected in communications from small and medium size companies in small Member States (this is the case in Latvia) as they cover a small market share and big manufacturers may not be interested in additional efforts for those companies. The involvement of associations could be with high added value in the information dissemination process Help desks in each Member State (Anonymous, 2006), where information can be received on the REACH regulation, shall be announced widely.

\section{Tools for providing information}

As mentioned previously, tools exist to provide information to other actors in the chemical supply chain.

Classification and labelling of hazardous chemicals is required by the EU directives, which have been amended a number of times. Council Directive 67/548/EEC for classification, labelling and packaging sets requirements for classification of substances and Council Directive 1999/45/EC sets the criterion how to classify chemical preparations. It is important to highlight that a manufacturer is not obliged to perform any tests and classification needs to be based on the available data. Thus, the previous system actually created an incentive to avoid safety testing (Warhurst, 2006). $\mathrm{REACH}$ requires to compile data on chemicals to be registered before they are placed on the market. Nevertheless, a part of substances, i.e. less than 1 ton per year manufactured or imported, for which data will not be gathered and substances will be in commerce, creating uncertainty regarding inherent properties causing harm. An efficient system for chemical control should therefore include mechanisms that encourage manufactures to obtain knowledge also beyond that legally required and to make this information available to users of their products (Hansson, 2006).

A Globally Harmonised System of classification and labelling of chemicals (GHS) (Anonymous, 2003) will be implemented as the EU regulation and will set new criteria to classify and label (Anonymous, 2007c). The GHS contains classification criteria for physical hazards, toxic (health) effects and environmental hazards of substances and mixtures (the name for preparations in the GHS). The new regulation will include new hazard symbols, e.g. health hazard symbol, which will be introduced to actors in the supply chain to understand the meaning and potential risk.
A safety data sheet (SDS) will be prepared by the manufacturer, importer or downstream user for chemical substance and preparations if there are met criteria identified in $\mathrm{REACH}$. It can be assumed that due to new data generation and compilation for the registration process, available information in this document will be more complete. SDS includes information on the following points (European Union, 2006):

1) identification of the substance/preparation and of the company/undertaking;

2) hazards identification;

3) composition/information on ingredients;

4) first-aid measures;

5) fire-fighting measures;

6) accidental release measures;

7) handling and storage;

8) exposure controls/personal protection;

9) physical and chemical properties;

10) stability and reactivity;

11) toxicological information;

12) ecological information;

13) disposal considerations;

14) transport information;

15) regulatory information;

16) other information.

Any actor registering a substance in a quantity of 10 tons or more per year will need to prepare a chemical safety report and add the relevant exposure scenarios in the annex of SDS covering identified uses and including specific conditions. Also, a downstream user will include exposure scenario and use information from SDS, when compiling their own SDS. This is a new requirement for actors in the supply chain and it could be a challenge, since information is needed on uses of substance and to assess and describe the risks. As it was mentioned before a downstream user may provide information to the supplier on the use of a substance for preparation of exposure scenario. REACH requires that distributors shall pass on such information to the next actor or distributor up the supply chain.

New requirements within REACH and the coming GHS regulation will push industry to follow the new requirements and invest time and human resources in order to reclassify substances and preparations and update information. SDS has been already required before, thus it is not a new task and practice has already been gained for companies in their elaboration. The EU chemical industry comprises about 27000 enterprises, 96\% of which have less 
than 250 employees and may be considered as small and medium sized enterprises. These account for $30 \%$ of sales and $37 \%$ of employment (Anonymous, 2007b). It may be hard work for small and medium-size companies to follow requirements and gain knowledge on new classification criteria, since usually they do not have expertise at the company level. Some companies are aware of changes and plan their own activities avoiding potential pressure to their business, e.g. to cease import from non-EU countries.

\section{CURRENTLY FUNCTIONING CHEMICAL MANAGE- MENT MODEL}

Risks posed by chemical substances might have a negative impact locally, e.g., in a country within its boarder, as well as could have impact to neighbouring or other distant regions.

Various international agreements, e.g. conventions, protocols, exist related to the management of hazardous substances on a global scale. Some of them are the following: Agenda 21: Chapter 19 "Environmentally sound management of toxic chemicals, including prevention of illegal international traffic in toxic and dangerous products" adopted at the United Nations Conference on Environment and Development, Rio de Janeiro, 1992; Rotterdam Convention on the Prior Informed Consent Procedure for Certain Hazardous Chemicals and Pesticides in International Trade; Stockholm Convention on Persistent Organic Pollutants; POP Protocol of the UNECE Convention on Long-Range Transboundary Air Pollution. International approaches to the management of chemicals vary considerably. It has been concluded that the chemicals management model in the United States of America relies more on voluntary programmes and is based on risk assessment and cost-benefit analyses in comparison to REACH (Crawford and Williams, 2006).

The European Union sets the legislative basis for safety on chemicals in different areas: product safety (e.g., Directive 2001/95/EC on General Product Safety, Directive 88/378/EEC on the Safety of Toys, Directive 76/768/EEC on Cosmetic Products), protection of environment (e.g., REACH, Directive 96/61/EC IPPC, Directive 1999/13/EC on VOC emissions from installations), work safety (e.g., Chemical Agent directive 98/24/EC) and others. It is important that legislative interfaces are developed ensuring the transfer of REACH results in the implementation of sectoral environmental law such as directives on industrial installations, water quality and waste management. The instruments laid down in these directives could support risk minimisation under REACH (Fuhr and Bizer, 2007).

Each Member State is responsible for implementation of the EU requirements of legal acts requirements into national legislation and set responsibilities for state authorities ensuring implementation and enforcement. Chemical assessment and control legislative systems in many countries are comprehensive and also regulation of chemicals may be covered by more than one piece of legislation (Winder and Azzi, 2005). In a case study the situation in Latvia has been analysed in regard to how responsibilities are distributed among state authorities (Figure 2).

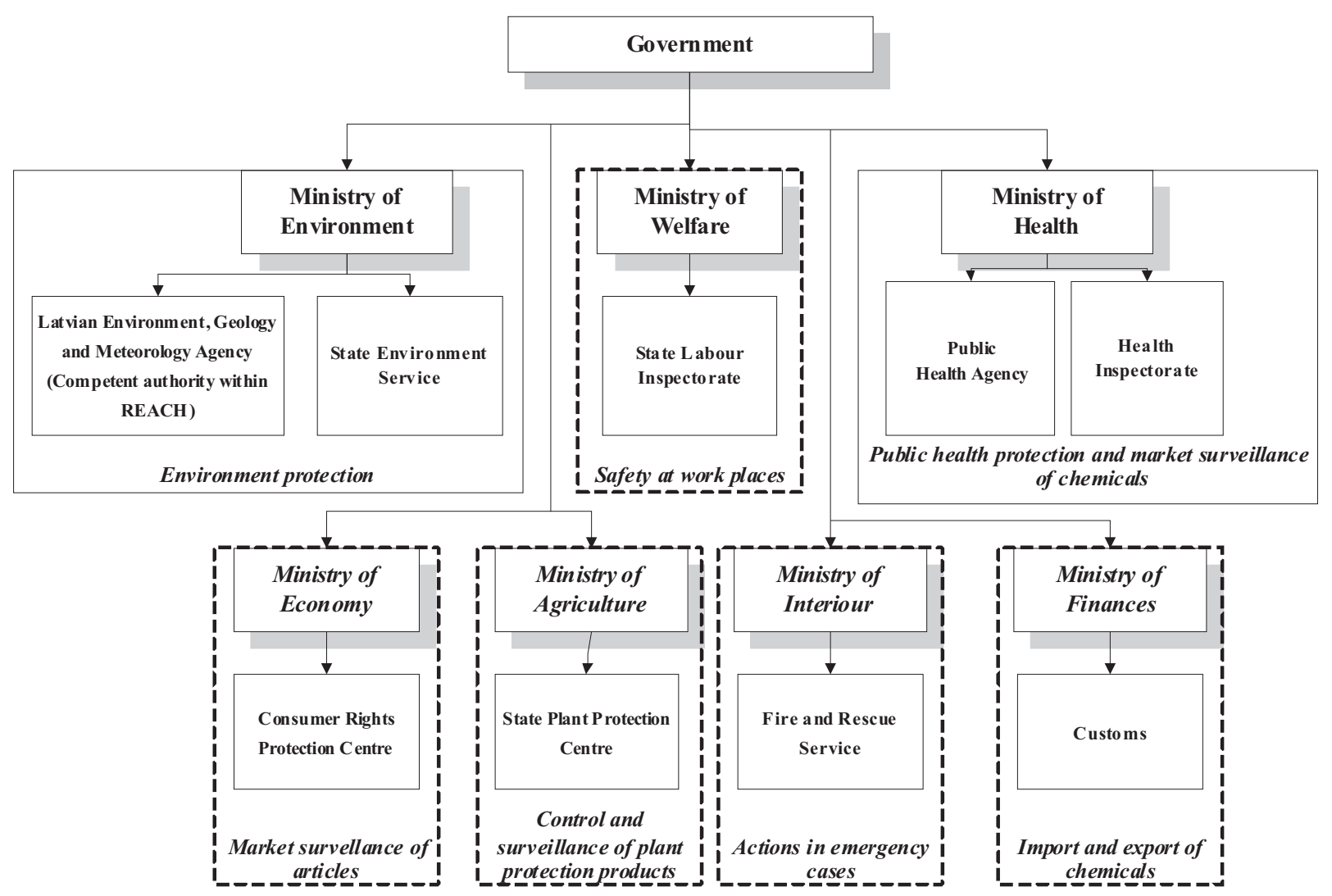

Fig. 2. Organisation of public institutions/state authorities in Latvia in the scope of chemical management actors. 
Figure 2 shows that state authorities from different areas are involved in chemicals management such as environmental protection, human health protection, market surveillance and others, as is the case for the majority of the EU Member States. It may be concluded that various state authorities are involved in chemical management and there is a necessity for strong co-operation and exchange of information to ensure effective management. The working group of Chemicals under the Ministry of Environment of the Republic of Latvia exists and consists of representatives from authorities dealing with chemical issues. It is a valuable instrument/ tool for information exchange on new or problematic issues on a country level.

Certain $\mathrm{REACH}$ requirements are in force already from 1 June 2007. Directive 91/155/EC is repealed and REACH includes requirements related to safety data sheets. Enforcement authorities will monitor SDS according to REACH from the date when it becomes in force. In the beginning stage, when REACH is not fully in force, there will be no substantial changes in SDS.

Totally new requirements within REACH for manufacturers and importers are pre-registration of produced or imported substances, but this is not mandatory. However, companies shall take into account that pre-registration has a transitional regime and REACH articles will not apply to preregistered substances by 1 December 2010 .

The fulfilment of this requirement is of high importance for companies that plan to produce or import substances in amounts relevant to REACH thresholds. If the company will not provide to the European Chemicals Agency information, including the name of substance, name and address of the companies, the name of contact person and envisage a deadline of the registration and the tonnage band, then it will not be able to benefit from transitional regime.

Thus, company awareness on pre-registration and dates (in total only six months) will be raised and information widely spread on a country level. Help desks at competent authorities are information dissemination centres and it would be advisable to co-operate with mass media and other state authorities to reach as many companies as possible dealing with chemicals.

A critical issue considering the implementation of REACH can be related to resources needed for implementation of the directive and relevant national legislation. Various estimations on the direct costs induced by REACH have been made. The European Commission's impact assessment estimated that REACH would cost the EU chemical industry around $€ 2.3$ billions over 11 years, with a maximum total cost on industry of $€ 5.2$ billion, with health benefits of at least $€ 50$ billions (Anonymous, 2003). In agreement with World Bank estimates, these studies indicate that the positive public health and occupational impact of REACH will lead to potential health benefits and savings evaluated at approximately 50 billion Euros over a 30 -year period due to the reduced burden associated with various diseases caused by chemicals (Lewis et al., 2007).

\section{CONCLUSIONS}

Analyses of recent chemical policies regarding chemicals classification and labelling, restrictions on marketing and use, approach of "new chemicals" shows several problems. The main problems concern lack of available information on the hazardous properties and uses of existing chemicals, low level of innovations in the chemical industry, unequal requirements for marketing and use between new chemicals and existing chemicals, and inadequate division of responsibility. Thus, previous approaches in management of chemicals substances were not sufficient to ensure a high level of protection of human health and the environment.

The new approach integrated in REACH is based on the precautionary principle. In the frame of implementation of the new EU chemical policy- $\mathrm{REACH}$ requires revision and development of new models of chemicals supply chain, information flows within chemicals supply chain and involved actors. The available data in Latvia shows that there are many involved actors in the management of chemical substances and thus it is important to ensure sufficient co-operation. New solutions for chemical management need to be elaborated on the country level taking into account the existing system and possible ways for effective integration of new approaches.

\section{ACKNOWLEDGMENTS}

The European Social Fund financially supported this study.

\section{REFERENCES}

Anonymous (1987). The International Labour Organisation: Safety in the Use of Chemicals at Work. Geneva: WLO. $80 \mathrm{pp}$.

Anonymous (1991). Commission Directive 91/155/EEC of 5 March 1991 defining and laying down the detailed arrangements for the system of specific information relating to dangerous preparations in implementation of Article 10 of Directive 88/379/EEC. European Union. Brussels. http://www.reach-compliance.eu/english/legislation/docs/european-union/ 91-155-EEC.pdf

Anonymous (1992). Council Directive 92/32/EEC of 30 April 1992 amending for the seventh time Directive 67/548/EEC in the approximation of the laws, regulations and administrative provisions relating to the classification, packaging and labelling of dangerous substances. European Union. Brussels.

http://eur-lex.europa.eu/smartapi/cgi/sga_doc?smartapi!celexplus!prod! CELEXnumdoc\&lg=en\&numdoc $=61996 J 0218$

Anonymous (1998a). Law on chemical substances and chemical preparations. Republic of Latvia. http://www.likumi.lv

Anonymous (1998b). Report on the operation of Directive 67/548/EEC, Directive 88/379/EEC, Regulation (EEC) 793/93 and Directive 76/769/EEC. European Commission. Brussels. http://ec.europa.eu/environment/chemicals/pdf/report-4-instruments_en.pdf

Anonymous (2003a) Globally Harmonized System of Classification and Labelling of Chemicals. United Nations Environment Programme (UNEP) http://www.unece.org/trans/danger/publi/ghs/ghs_welcome_e.html

Anonymous (2003b). Regulation of the European Parliament and of the Council concerning the Registration, Evaluation, Authorisation and Restrictions of Chemicals (REACH), establishing a European Chemicals Agency and amending Directive 1999/45/EC and Regulation (EC). Extended Impact Assessment. European Commission. Brussels. 
http://ec.europa.eu/environment/chemicals/reach/background/docs/ eia-sec-2003_1171.pdf

Anonymous (2005a). Marketing restrictions website. European Commission. Brussels. http://europa.eu.int/comm/enterprise/chemicals/legislation/ markrestr/

Anonymous (2005b). New Chemicals website. European Chemicals Bureau. Ispra. http://ecb.jrc.it/new-chemicals/

Anonymous (2006). Regulation (EC) No 1907/2006 of the European Parliament and of the Council of 18 December 2006 concerning the Registration, Evaluation, Authorisation and Restriction of Chemicals (REACH), establishing a European Chemicals Agency, amending Directive 1999/45/EC and repealing Council Regulation (EEC) No 793/93 and Commission Regulation (EC) No 1488/94 as well as Council Directive 76/769/EEC and Commission Directives 91/155/EEC, 93/67/EEC, 93/105/EC and 2000/21/EC. European Union. Brussels.

http://eur-lex.europa.eu/LexUriServ/LexUriServ.do?uri=CELEX: 32006R1907:EN:NOT

Anonymous (2007a). Consultation on the enforcement of REACH in the UK. DEFRA. http://www.defra.gov.uk/corporate/consult/reach-enforce/index.htm

Anonymous (2007b). Facts and Figures. European Chemical Industry Council (CEFIC). http://www.cefic.org/factsandfigures/level02/profile_index.html

Anonymous (2007c). Proposal for a Regulation of the European Parliament and of the Council on classification, labeling and packaging of substances and mixtures, and amending Directive 67/548/EEC and Regulation (EC) No 1907/2006 (presented by the Commission). European Commission. Brussels.

http://eur-lex.europa.eu/LexUriServ/LexUriServ.do?uri=COM:2007:035 5:FIN:EN:HTML
Crawford, E., Williams, T. (2006) International Management of Chemicals, PRB 06-29E. http://www.parl.gc.ca/information/library/PRBpubs/ prb0629-e.htm

Fuhr, M., Bizer K.K. (2007) REACH as a paradigm shift in chemical policy-responsive regulation and behavioural models. J. Cleaner Prod., 15, $327-334$.

Hansson, S.O., Ruden, C. (2006) Priority setting in the REACH system. Toxicol. Sci., 90(2), 304-308.

Lewis, A., Kazantzis, N., Fishtik, I., Wilcox, J. (2007) Integrating process safety with molecular modelling-based risk assessment of chemicals within the REACH regulatory framework: Benefits and future challenges. J. Haz. Mat., 142, 592-602.

Lokke, S. (2006) The precautionary principle and chemicals regulation. Environ. Sci. Pollut. Res., 13(5), 342-349.

Lönngren, T. (1992) International Approaches to Chemicals Control, a Historical Overview. Sweden, $512 \mathrm{pp}$.

Pedersen, F., de Bruijn, J., Munn, S., van Leeuwen, K. (2003) Assessment of additional testing needs under REACH: Effects of (Q)SARS, risk based testing and voluntary industry initiatives. European Commission Joint Research Centre, Institute for Health and Consumer Protection. http://ihcp.jrc.cec.eu.int/DOCUMENTATION/IHCP_Reports/ REACH\%20testing\%20needs\%20final.pdf

Walker, C.H., Hopkin, S.P., Sibly, R.M., Peakall, D.B. (2001) Principles of Ecotoxicology, 2nd ed. Glasgow: Bell \&Baint Ltd. 309 pp.

Warhurst, A.M. (2006) Assessing and managing the hazards and risks of chemicals in the real world - the role of the EU's REACH proposal in future regulation of chemicals. Environ. Internat., 32, 1033-1042.

Winder, C., Azzi, R. (2005) The development of the globally harmonised system (GHS) of classification and labelling of hazardous substances. $J$. Haz. Mat., A125, 29-44.

Received 22 January 2008

\section{ĶĪMISKO VIELU PĀRVALDĪBAS ATTĪSTĪBA: IZAICINĀJUMI UN RISINĀJUMI}

Pētīti ķīmisko vielu pārvaldību noteicošie faktori - vides likumdošanas prasības, to praktiskās ieviešanas problēmas. Analizētas iespējamās

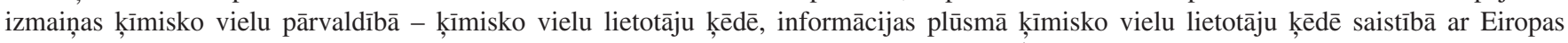
Savienības ķīmisko vielu likumdošanas jaunajām prasībām, kas paredz ķīmisko vielu reğistrācijas, izvērtēšanas un licencēšanas sistēmu (regulu) - ,Registration, Evaluation and Authorisation of Chemicals”, saīsinājumā - REACH. REACH regula ietver integrētu skatījumu uz kīimisko vielu ražošanu, transportu un lietošanu ES līmenī. Jaunā pieeja izvirza prasības papildināt informāciju arī par tirgū esošajām ķīmiskajām vielām, saistītajai informācijas plūsmai, līdzvērtīgu atbildības sadalījumu starp visiem kīmisko vielu apritē iesaistītajiem dalībniekiem. 